\title{
REVIEW
}

\section{Biomarkers in spinal cord injury}

\author{
MH Pouw ${ }^{1}$, AJF Hosman $^{1}, \mathrm{JJ}_{\text {van Middendorp }}{ }^{1}, \mathrm{MM} \mathrm{Verbeek}^{2},{\mathrm{PE} \operatorname{Vos}^{3} \text { and } \mathrm{H} \text { van de Meent }}^{4}$ \\ ${ }^{1}$ Department of Orthopedic Surgery, Radboud University Nijmegen Medical Centre, Nijmegen, The Netherlands; ${ }^{2}$ Laboratory \\ of Pediatrics and Neurology, Institute for brain, cognition and behavior, Radboud University Nijmegen Medical Centre, Nijmegen, \\ The Netherlands; ${ }^{3}$ Department of Neurology, Radboud University Nijmegen Medical Centre, Nijmegen, The Netherlands and \\ ${ }^{4}$ Department of Rehabilitation Medicine, Radboud University Nijmegen Medical Centre, Nijmegen, The Netherlands
}

\begin{abstract}
Study design: Literature review.
Objectives: In traumatic spinal cord injury $(\mathrm{SCl})$, much effort has been put into the evaluation of $\mathrm{SCl}$ severity and the prediction of recovery potential. An accurate prediction of the initial damage of the spinal cord that differentiates between the severities of $\mathrm{SCl}$ however, may help physicians in choosing a particular neuroprotective treatment in the acute phase. Neurochemical biomarkers may possibly fulfil these requirements. The aim of this review was to describe (1) the current status of neurochemical biomarkers in SCl; (2) their potential diagnostic role in $\mathrm{SCl}$.

Methods: MEDLINE was searched from 1966 to 2008 to identify publications concerning biomarkers in traumatic $\mathrm{SCl}$.

Results: The biomarkers S-100 $\beta$, neuron-specific enolase, neurofilament light chain, and Glial fibrillary acidic protein are significantly increased in cases of (experimental) spinal cord injury. Furthermore, increased serum concentrations of $\mathrm{S}-100 \beta$ have been correlated with an unfavourable functional outcome. Although biomarkers in $\mathrm{SCl}$ show promising results, considerations and shortcomings, such as polytrauma, haemolysis, extracerebral sources, and poor resuscitation, must be studied in greater detail before biomarkers can be utilised in the clinical care of $\mathrm{SCl}$.

Conclusions: Quantitative standards for determining the extent of $\mathrm{SCl}$ during the acute phase must be developed and validated. Even though increased concentrations of neurochemical biomarkers have been identified in patients with $\mathrm{SCl}$, these do not yet provide a sensitive prognostic tool. Considering the limited availability of sensitive prognostic tools, neurochemical biomarkers of $\mathrm{SCl}$ should be evaluated and validated in future clinical trials.
\end{abstract}

Spinal Cord (2009) 47, 519-525; doi:10.1038/sc.2008.176; published online 20 January 2009

Keywords: biomarkers; spinal cord injury; cerebrospinal fluid; serum; trauma

\section{Introduction}

In traumatic spinal cord injury (SCI), much effort has been put into the evaluation of SCI severity and prediction of recovery potential. Interventions for the recovery of function following SCI include a combination of pharmacological, $^{1}$ surgical ${ }^{2}$ and rehabilitation ${ }^{3}$ approaches. The benefits of these interventions, however, are not univocal in clinical trials. It is assumed that patients with more severe SCI respond differently to neuroprotective interventions than do patients with less severe SCI. ${ }^{3}$ An accurate prediction of the initial damage of the spinal cord that differentiates between the different severities of SCI may help physicians in

Correspondence: Dr MH Pouw, Department of Orthopedic Surgery, Radboud University Nijmegen Medical Centre, Theodoor Craanenlaan 7, Postbox 9101, Nijmegen 6500 HB, The Netherlands.

E-mail: M.Pouw@orthop.umcn.nl

Received 26 September 2008; revised 1 December 2008; accepted 10 December 2008; published online 20 January 2009 choosing an available or experimental neuroprotective intervention in the very acute phase.

Conventional magnetic resonance imaging (MRI) is currently the best imaging modality for evaluating traumatic SCI during the very acute phase. ${ }^{4}$ Although several MRI findings such as parenchymal hemorrhage, transection and longer lesion length correlate with less favorable neurological outcomes, the findings on neurological examinations are most predictive of outcomes. ${ }^{5}$ Prediction of functional outcome by means of the American Spinal Injury Association (ASIA) motor scores is considered to be reliable and prognostic in patients with motor complete SCI when tested $72 \mathrm{~h}$ after the initial trauma. ${ }^{6,7}$ Combining the results of MRI and initial neurological examination results in an even better prediction of the recovery of motor scores. ${ }^{8,9}$ However, early ASIA examinations (for example, within $72 \mathrm{~h}$ post-injury) are considered unreliable. $^{6}$ 
Therefore, an early, accurate diagnostic test with the purpose of indicating neuroprotective interventions is preferable. Conventional MRI appears to be restricted to assessing macroscopic changes in the injured spinal cord, as it does not adequately address axonal injury in the white matter. As the degree and localization of injured and spared white matter primarily determine functioning after SCI, MRI has limited success as a prognostic tool. ${ }^{5}$ MRI is largely a qualitative measure and quantitative standards, in relation to functional SCI outcomes, will need to be developed and validated. $^{3}$

A new approach for evaluating the primary cord damage in the acute phase may be the assessment of biomarker concentrations in the cerebrospinal fluid (CSF). Trauma to the spinal cord causes an acute physical injury with neuronal necrosis. This is followed by a secondary axonal degeneration and further degeneration or death of nerve cells by either apoptosis or necrosis, processes that may last between days and weeks. As the spinal cord is surrounded by the CSF, damage to the spinal cord may lead to the release of proteins and metabolites from the nervous tissue into the CSF. This process allows for the study of 'biomarkers' of SCI in the CSF. $^{10-12}$ A biomarker is a characteristic that is objectively measured and evaluated as an indicator of normal or pathologic processes or pharmacologic responses to a therapeutic intervention. ${ }^{13}$

Biomarkers of SCI can be approached in two ways: (1) a direct survey of primary structural damage using a specific unique marker (or markers) of tissue damage, and (2) measure aspects of the cellular, biochemical or molecular cascades in the secondary injury (or repair) response phase. ${ }^{14}$ An ideal prognostic central nervous system (CNS) biochemical marker should have all of the following properties: ${ }^{15}$

1. central nervous system specificity;

2. rapid and significant release into blood or CSF after injury;

3. readily obtainable assay results;

4. predictability of serious injury from an early sample;

5. relationship of marker concentration with the degree of injury;

6. inexpensive;

7. minimally influenced by confounding factors;

8. reproducible.

There has been growing interest in biomarkers as indicators of tissue destruction in CNS diseases. Several studies have indicated that monitoring the levels of neuron-, myelin- or astroglia-specific proteins in the serum and CSF may be a useful approach for evaluating the severity of nontraumatic CNS injury. ${ }^{11,12,16,17}$

Several studies have been published concerning the use of biomarkers in CSF and serum of patients with traumatic brain injury. ${ }^{18-21}$ A recent review discussed the role of biomarkers in traumatic brain injury. ${ }^{14}$ In the field of SCI, however, there is no review on the value of biomarkers.

The aim of this literature review is to describe the current status of neurochemical biomarkers and their potential diagnostic value from either experimental models or patient series of acute SCI. This review focuses on the markers that survey direct structural damage.

\section{Methods}

Clinical and experimental studies that included biomarkers investigating direct structural damage in serum and/or CSF after an SCI in humans or animals were eligible for this review.

We searched MEDLINE (PubMed interface), EMBASE and reference lists of the included articles published between 1966 and November 2008. In MEDLINE, we used a combination of the following search terms: diagnosis, spinal cord, trauma, biomarker, cerebrospinal fluid and serum. Furthermore, the references of retrieved publications were checked manually for additional studies that could potentially meet the inclusion criteria.

\section{Results}

The search strategy resulted in 250 potentially relevant articles from MEDLINE. The search in other databases yielded no additional relevant articles. A review of the titles, abstract and the full text resulted in the inclusion of 18 articles. Twelve studies investigated biomarkers in humans $^{22-32}$ and six studies investigated biomarkers in animals. ${ }^{33-38}$ Relatively few studies have been performed in which biomarkers in serum and/or CSF after SCI were investigated. For those that have been conducted, S-100 $\beta$ and neuron-specific enolase (NSE) have especially received attention. An overview is shown in Tables 1 and 2 .

\section{Biomarkers in animal studies after SCI}

$S-100 \beta$. S-100 $\beta$ is a calcium-binding protein localized predominantly in astroglial and Schwann cells. ${ }^{39}$ In a model using Sprague-Dawley rats with SCI (induced by a weightdrop device), significantly increased serum and CSF levels of S-100 $\beta$ were observed compared with the control group without SCI at $6 \mathrm{~h}$ after the induced SCI. ${ }^{37}$ Another model using Sprague-Dawley rats identified a significant increase of S-100 $\beta$ serum concentrations after an SCI or a plexus avulsion injury compared with a control group. ${ }^{34}$

Neuron-specific enolase. Neuron-specific enolase is a glycolytic enzyme predominantly localized in the cytoplasm of neurons and cells of neuroendocrine lineage. ${ }^{40}$ Loy et al. ${ }^{37}$ assessed the NSE serum and CSF levels in a rat model using a weight-drop device to simulate SCI. Compared with the control group, the NSE levels in serum and CSF were significantly increased at $6 \mathrm{~h}$ after the induced SCI. The NSE levels in the two graded injured groups did not differ significantly. Another study simulating ischemic SCI using thoracoabdominal aortic cross-clamping in 10 dogs identified significantly elevated NSE levels in CSF during clamping and reperfusion. ${ }^{35}$ 
Table 1 Included animal studies

\begin{tabular}{|c|c|c|c|c|}
\hline Study & $\begin{array}{l}\text { Biomarker } \\
\text { investigated }\end{array}$ & CSF/serum & Details of study (sub) groups & Results \\
\hline Skouen et al. ${ }^{33}$ & $\begin{array}{l}\text { S-100 } \beta, N F L, N S E \\
\text { and GFAP }\end{array}$ & CSF & $\begin{array}{l}18 \text { pigs underwent an experimental nerve } \\
\text { root injury and } 18 \text { pigs were used as sham } \\
\text { operated animals. } \\
\text { Control: } 5 \text { pigs without nerve root injury }\end{array}$ & $\begin{array}{l}\text { At } 1 \text { week after the experimental } \\
\text { nerve root injury, NFL concentrations } \\
\text { were elevated }(P<0.001) \text {. } \\
\text { Nonsignificant differences of S-100 } \beta \text {, } \\
\text { NSE and GFAP concentrations were } \\
\text { identified after the induced nerve } \\
\text { root injury. }\end{array}$ \\
\hline Ma et al. ${ }^{34}$ & $S-100 \beta$ & Serum & $\begin{array}{l}40 \text { Sprague-Dawley rats in a weight-drop } \\
\text { model and } 66 \text { Sprague-Dawley rats with } \\
\text { induced lumbar plexus avulsion injury. } \\
\text { Control: } 28 \text { Sprague-Dawley rats without SCl } \\
\text { or plexus injury. }\end{array}$ & $\begin{array}{l}\text { At } 3,12 \text { and } 72 \mathrm{~h} \text { after } \mathrm{SCl} \text {, increased } \\
\text { levels of } \mathrm{S}-100 \beta(P<0.05) \text { were } \\
\text { identified. }\end{array}$ \\
\hline Nagy et al. ${ }^{35}$ & NSE & CSF & $\begin{array}{l}10 \text { dogs who underwent thoracoabdominal } \\
\text { cross-clamping. }\end{array}$ & $\begin{array}{l}\text { At } 55 \text { min of clamping, increased } \\
\text { levels of NSE were identified } \\
(P<0.05)\end{array}$ \\
\hline Cornefjord et $a l^{36}$ & $\begin{array}{l}\text { S-100 } \beta, N F L, N S E \\
\text { and GFAP }\end{array}$ & CSF & $\begin{array}{l}20 \text { pigs were divided in four groups ( } n=5 \\
\text { each): ( } 1 \text { ) experimental nerve root injury, }(2) \\
\text { autologous nucleus pulposus application, }(3) \\
\text { experimental nerve root injury and nucleus } \\
\text { pulposus application. } \\
\text { Control: (4) sham operation. }\end{array}$ & $\begin{array}{l}\text { At } 1 \text { week after the experimental } \\
\text { nerve root injury, NFL concentrations } \\
\text { were elevated }(P<0.01) \text {. } \\
\text { Nonsignificant differences of } S-100 \beta \text {, } \\
\text { NSE and GFAP concentrations were } \\
\text { identified after the induced nerve } \\
\text { root injury. }\end{array}$ \\
\hline Loy et $a .^{37}$ & S-100 $\beta$ and NSE & Serum & $\begin{array}{l}34 \text { Sprague-Dawley rats in a weight-drop } \\
\text { model. } \\
\text { Control: } 6 \text { Sprague-Dawley rats without SCI. }\end{array}$ & $\begin{array}{l}\text { At } 6 \mathrm{~h} \text { after } \mathrm{SCl} \text {, increased levels of } \\
\mathrm{S}-100 \beta(P<0.05) \text { and NSE } \\
(P<0.001) \text { were identified. }\end{array}$ \\
\hline Cao et al. $^{38}$ & S- $100 \beta$ and NSE & Both & $\begin{array}{l}60 \text { Sprague-Dawley rats in a weight-drop } \\
\text { model. } \\
\text { Control: } 20 \text { Sprague-Dawley rats without } \\
\text { SCI. }\end{array}$ & $\begin{array}{l}\text { At } 2 \mathrm{~h} \text { after the force-defined } \mathrm{SCl} \text {, } \\
\text { serum and } \mathrm{CSF} \text { concentrations were } \\
\text { elevated }(P<0.05) \text {. }\end{array}$ \\
\hline
\end{tabular}

Abbreviations: CSF, cerebrospinal fluid; GFAP, Glial fibrillary acidic protein; NFL, neurofilament protein; NSE, neuron-specific enolase; SCl, spinal cord injury.

\section{Time-dependency of biomarkers}

Cao et al. ${ }^{38}$ evaluated the relationship between the protein levels of NSE and S-100 $\beta$ in serum and CSF and the severity of acute SCI in an animal model. Eighty Sprague-Dawley rats were divided into four groups: control group, mild SCI group, moderate SCI group and severe SCI group. Graded SCI was provided using a weight-drop model from different heights. Serum and CSF samples were collected at different time points. When compared with the control group, the concentrations of NSE and S-100 $\beta$ were significantly $(P<0.05)$ increased at $2 \mathrm{~h}$ after SCI and reached maximum levels at $6 \mathrm{~h}$. The NSE and S-100 $\beta$ levels in the moderate and severe SCI groups were significantly higher $(P<0.05)$ than the NSE and S-100 $\beta$ levels in the mild SCI group. At $24 \mathrm{~h}$ after injury, the NSE and S-100 $\beta$ levels in the serum and CSF were still significantly higher than those in the control group. However, after $24 \mathrm{~h}$, the graded SCI groups did not differ significantly.

It is hypothesized that the peak in the concentration of NSE and S- $100 \beta$ after $6 \mathrm{~h}$ reflects a mechanical disruption of the spinal cord. Furthermore, the concentration of NSE and $\mathrm{S}-100 \beta$ is positively correlated with the grade of the SCI. This study indicates that the NSE and S-100 $\beta$ alterations are time dependent and positively correlated with the severity of the trauma. Although the correlations between the neurophysiological findings and/or radiographic abnormalities and changes of biomarkers after trauma were not assessed, this study suggests that both biomarkers reflect neuronal and glial damage induced during the acute phase of SCI.

Nerve root injury. Although a nerve root compression is not a CNS injury, the role of biomarkers in nerve root injury is addressed. From earlier studies, it is known that a breakdown of the blood-nerve barrier occurs in compressed nerve roots. ${ }^{41}$ This may result in a detectable elevation of biomarkers in CSF.

In a pig model investigating biomarkers after experimental nerve root injury, unilateral compression of the nerve root of S1 was obtained by means of an ameroid constrictor. ${ }^{33}$ Compared with the control group, pigs with an experimental nerve root injury had elevated NFL levels in CSF 1 week after the induced injury. ${ }^{33}$ Another pig model also investigated several biomarkers in CSF in an experimental nerve root injury model of S1. ${ }^{36}$ Twenty pigs were divided into four groups: (1) slow-onset mechanical compression with an ameroid constrictor; (2) harvested autologous nucleus pulposus applied to the nerve root; (3) mechanical compression plus harvested autologous nucleus pulposus; (4) sham operation. Significantly increased concentrations of neurofilament protein (NFL) in CSF after mechanical compression on spinal nerve roots were identified compared with the nucleus pulposus group and sham group after 1 week. ${ }^{36}$ The results of these 
Table 2 Included human studies

\begin{tabular}{|c|c|c|c|c|}
\hline Study & $\begin{array}{l}\text { Biomarker } \\
\text { investigated }\end{array}$ & CSF/serum & Details of study (sub) groups & Results \\
\hline $\begin{array}{l}\text { Van Dongen } \\
\text { et al. }{ }^{23}\end{array}$ & $S-100 \beta$ & Both & $\begin{array}{l}8 \text { patients who underwent elective TAAA } \\
\text { surgery. }\end{array}$ & $\begin{array}{l}\text { Nonsignificantly elevated S- } 100 \beta \text { CSF } \\
\text { concentrations. Serum concentrations } \\
\text { were not elevated. }\end{array}$ \\
\hline $\begin{array}{l}\text { Van Dongen } \\
\text { et } \text { al. }^{22}\end{array}$ & S- $100 \beta$ & CSF & $\begin{array}{l}19 \text { patients who underwent elective TAAA } \\
\text { surgery. }\end{array}$ & $\begin{array}{l}\text { Non-significantly elevated S- } 100 \beta \\
\text { concentrations. }\end{array}$ \\
\hline Brisby et al. ${ }^{25}$ & S-100 $\beta$ and NSE & CSF & $\begin{array}{l}15 \text { patients who underwent surgery due } \\
\text { to a lumbar disc herniation. } \\
\text { Control: } 7 \text { patients without lumbar disc } \\
\text { herniation. }\end{array}$ & $\begin{array}{l}\text { Concentrations of NFL }(P<0.01) \text { and } \\
\text { S- } 100 \beta(P<0.05) \text { were elevated in } \\
\text { patients with lumbar disc herniation. } \\
\text { NSE and GFAP concentrations were } \\
\text { nonsignificantly elevated. }\end{array}$ \\
\hline Kunihara et al. ${ }^{42}$ & $S-100 \beta$ & Both & $\begin{array}{l}23 \text { patients who underwent thoracic aorta } \\
\text { or TAAA surgery. }\end{array}$ & $\begin{array}{l}\text { At } 6 \mathrm{~h} \text { after surgery, increased levels of } \\
\mathrm{S}-100 \beta(P<0.01) \text { were identified in four } \\
\text { patients with post-operative SCI. }\end{array}$ \\
\hline Ohta et al. ${ }^{26}$ & MBP & Both & $\begin{array}{l}36 \text { patients with tropical spastic } \\
\text { paraparesis. } \\
\text { Control: } 45 \text { patients with non- } \\
\text { neurological diseases and } 70 \text { healthy } \\
\text { subjects. }\end{array}$ & $\begin{array}{l}\text { Elevated CSF MBP concentrations were } \\
\text { identified in patients with tropical spastic } \\
\text { paraparesis }(P<0.001) \text {. Nonsignificantly } \\
\text { elevated serum MBP concentrations were } \\
\text { detected. }\end{array}$ \\
\hline Guez et al. ${ }^{27}$ & GFAP and NFL & CSF & $\begin{array}{l}6 \text { patients with traumatic } \mathrm{SCl} \text { and } 17 \\
\text { patients with a whiplash injury } \\
\text { Control: } 24 \text { neurologically healthy } \\
\text { individuals. }\end{array}$ & $\begin{array}{l}\text { Nonsignificantly elevated levels of NFL } \\
\text { and GFAP were identified in all SCI } \\
\text { patients. }\end{array}$ \\
\hline Shiiya et al. ${ }^{28}$ & Tau and $S-100 \beta$ & CSF & $\begin{array}{l}28 \text { patients who underwent elective } \\
\text { prosthetic replacement of the descending } \\
\text { thoracic aorta or TAAA. }\end{array}$ & $\begin{array}{l}\text { Nonsignificantly elevated levels of Tau. At } \\
6 \mathrm{~h} \text { after surgery, elevated levels of } \mathrm{S}-100 \beta \\
(P<0.05) \text { were identified in three patients } \\
\text { with post-operative } \mathrm{SCl} \text {. }\end{array}$ \\
\hline $\begin{array}{l}\text { Marquardt } \\
\text { et al. }{ }^{29}\end{array}$ & $S-100 \beta$ & Serum & $\begin{array}{l}11 \text { patients with spinal epidural } \\
\text { empyema; S- } 100 \beta \text { measurements were } \\
\text { correlated with clinical outcome. }\end{array}$ & $\begin{array}{l}\text { Patients with increased levels for a } \\
\text { minimum of } 3 \text { days had unfavorable } \\
\text { outcome }(P<0.003) \text {. }\end{array}$ \\
\hline $\begin{array}{l}\text { Marquardt } \\
\text { et } \text { al. }^{29}\end{array}$ & $S-100 \beta$ & Serum & $\begin{array}{l}34 \text { patients with paresis due to spinal } \\
\text { metastasis; } S-100 \beta \text { measurements were } \\
\text { correlated with clinical outcome. }\end{array}$ & $\begin{array}{l}\text { Patients with increased levels for a } \\
\text { minimum of } 10 \text { days had unfavorable } \\
\text { outcome }(P<0.0001) \text {. }\end{array}$ \\
\hline $\begin{array}{l}\text { Brunnekreef } \\
\text { et al. }{ }^{24}\end{array}$ & S-100 $\beta$ & CSF & $\begin{array}{l}8 \text { patients who underwent elective TAAA } \\
\text { surgery. }\end{array}$ & $\begin{array}{l}\text { Non-significantly increased levels of } \\
\text { S-100 } \beta \text { were detected. }\end{array}$ \\
\hline $\begin{array}{l}\text { Winnerkvist } \\
\text { et al. }{ }^{31}\end{array}$ & $\begin{array}{l}\text { GFAP, NFL and } \\
\text { S- } 100 \beta\end{array}$ & CSF & $\begin{array}{l}39 \text { patients who underwent elective TAAA } \\
\text { surgery. }\end{array}$ & $\begin{array}{l}\text { At } 24 \mathrm{~h} \text { after surgery, increased levels } \\
\text { of } \mathrm{S}-100 \beta(P<0.05), \mathrm{NFL}(P<0.05) \text {, and } \\
\text { GFAP }(P<0.001) \text { were identified in five } \\
\text { patients with post-operative SCI. }\end{array}$ \\
\hline Khaladj et $a .^{32}$ & S-100 $\beta$ & Both & $\begin{array}{l}13 \text { patients who underwent elective TAAA } \\
\text { surgery. }\end{array}$ & $\begin{array}{l}\text { At } 6 \mathrm{~h} \text { after surgery, increased levels } \\
\text { of } \mathrm{S}-100 \beta(P<0.001) \text { were identified } \\
\text { in two patients with post-operative SCl. }\end{array}$ \\
\hline
\end{tabular}

Abbreviations: CSF, cerebrospinal fluid; GFAP, Glial fibrillary acidic protein; MBP, myelin basic protein; NFL, neurofilament protein; NSE, neuron-specific enolase; $\mathrm{SCl}$, spinal cord injury; TAAA, thoracoabdominal aortic aneurysm.

studies indicate that the compression of nerve roots can induce a significant increase in NFL, indicating nerve tissue damage. $^{33,36}$

\section{Biomarkers in patients after SCI}

$S-100 \beta$. In patients with thoracic and thoracoabdominal aortic aneurysms (TAAAs), surgical treatment may be associated with a significant risk of perioperative morbidity, including paraplegia. Several studies investigated the concentrations of S-100 $\beta$ in serum and CSF during and after thoracic endovascular stent grafting. Van Dongen et al. ${ }^{22,23}$ identified elevated CSF concentrations of S-100 $\beta$ in 19 patients undergoing TAAA surgery. The highest concentrations of S-100 $\beta$ were found in CSF samples taken 5 min after reperfusion. The authors suggest that the increased CSF $S-100 \beta$ after unclamping of the aorta indicates that there is a continuous release of $\mathrm{S}-100 \beta$ from ischemic neural tissue. ${ }^{22-24}$ Another study reevaluated the potential impact of S-100 $\beta$ in serum and CSF in 13 patients undergoing TAAA surgery. Compared with the patients without SCI, significantly elevated $(P<0.001)$ CSF concentrations of S-100 $\beta$ were identified in two patients with ischemic SCI $6 \mathrm{~h}$ after unclamping. ${ }^{32}$ In another study, significantly elevated serum and CSF concentrations of S-100 $\beta$ have also been identified $6 \mathrm{~h}$ after unclamping, compared with patients without SCI. ${ }^{42}$ Brunnekreef et al. ${ }^{24}$ evaluated S-100 $\beta$ CSF concentrations in eight patients who underwent TAAA surgery. However, there was no significant increase in S-100 $\beta$ CSF concentrations. It was suggested that an increased concentration of S-100 $\beta$ in CSF is a marker of spinal cord ischemia. ${ }^{22-24}$ In addition, the release of the biomarker S-100 $\beta$, neurofilament light chain protein (NFL), and Glial fibrillary acidic protein (GFAP) in CSF was investigated in another study in which 39 patients underwent TAAA surgery. ${ }^{31}$ Glial fibrillary acidic protein is a filament protein localized predominantly in astroglial 
cells. ${ }^{43}$ NFL is a structural protein of neurons and it is predominantly localized in the axons. ${ }^{44}$ In this study, CSF concentrations of S-100 $\beta$, NFL and GFAP were increased significantly in five patients $(P<0.05)$ with ischemic SCI compared with patients without SCI. ${ }^{31}$

Furthermore, the predictive potential of S- $100 \beta$ concentrations in serum has been analyzed in patients with spinal cord compression caused by epidural empyema and spinal metastasis. ${ }^{29,30}$ Clinical outcome was considered favorable in cases of motor score improvement and preservation or retrieval of walking ability, whereas no improvement or further neurologic deterioration without restoration of gait function was regarded to be unfavorable. Motor function was based on the strongest muscle group in the lower extremities using the $0-5$ rating system. Patients with epidural empyema and persistently increased S-100 $\beta$ levels for a minimum of 3 days after operative decompression had unfavorable functional outcome $(P<0.003)$, as measured by motor function. ${ }^{30}$ Patients with spinal metastasis and persistently increased S-100 $\beta$ levels for a minimum of 10 days after operative decompression had unfavorable functional outcome $(P<0.0001)$, as measured by motor function. ${ }^{29}$ As motor scores are not equal to a direct functional ambulation outcome measurement, ${ }^{45}$ patients with increased S-100 $\beta$ levels in these studies have unfavorable motor function, not unfavorable functional outcome.

Traumatic SCI. To our knowledge, Guez et al. ${ }^{27}$ conducted the only study that investigated biomarkers in patients with traumatic SCI. In this prospective study, 6 patients with traumatic SCI and 17 patients with a severe whiplash injury were compared with a control group of 24 neurologically healthy individuals. All individuals underwent a lumbar puncture. CSF concentrations of NFL and GFAP were analyzed. Nonsignificantly increased concentrations of NFL and GFAP were identified in CSF of all SCI patients compared with the control group of neurologically healthy individuals.

Myelin basic protein. Myelin basic protein (MBP) is a protein produced by oligodendrocytes and it is the major constituent of the myelin sheath of axons. ${ }^{46,47}$ No study has specifically investigated the role of MBP in traumatic SCI; however, a single study retrospectively identified higher CSF concentrations of MBP in patients with tropical spastic paraparesis compared with CSF of patients with non-neurological diseases. $^{26}$

Tau. Tau, a protein localized primarily in the neurons and especially in the axonal compartments, ${ }^{48}$ has been correlated with outcome in patients with traumatic brain injury. ${ }^{49}$ Alterations of CSF Tau levels were evaluated in a study with 28 patients undergoing aortic surgery. However, when compared with the group without any neurologic complications, the Tau levels were not significantly elevated in patients with postoperative SCI. ${ }^{28}$

Nerve root injury. The pathophysiologic mechanisms of disc herniation are not fully understood; however, herniated discs are believed to have direct mechanical effects on the nerve root. Brisby et al. ${ }^{25}$ assessed biomarkers in 15 patients with disc herniation who underwent surgery because of a lumbar disc herniation. Increased CSF concentrations of NFL and $S-100 \beta$ were identified when compared with the control group. Furthermore, patients with less than 3 months' duration of symptoms before surgery had significantly higher levels of NFL than did patients with more than 3 months' duration $(P<0.05)$. This may be consistent with a release of NFL from the damaged nerve of the compressed nerve root during the acute phase. The lower level of NFL in patients with long-standing chronic pain may have been caused by atrophy of the nerve root, which results in a lesser release of NFL. ${ }^{25}$

\section{Considerations}

In contrast to the large number of reports on biomarkers in structural brain damage, only a few studies have investigated the role of biomarkers in patients with SCI. Although studies investigating biomarkers in traumatic brain injury and SCI are promising, several considerations must be kept in mind before using them in the clinical care of SCI.

Most biomarker assays are not widely available in a standard clinical chemistry laboratory as these are 'specialty analyses' and are therefore available only in designated laboratories. However, standardized commercial assays are available for S-100 $\beta$ and NSE. Commercial assays are also available for Tau, GFAP and MBP. There is no commercial assay for NFL. It is expected that faster techniques will cause neurochemical biomarkers to be more readily obtainable; however, at this stage, most biomarker assays must be performed in designated laboratories.

The studies of Ohta et al. ${ }^{26}$ and Guez et al. ${ }^{27}$ showed that biomarker concentrations are not elevated in neurologically healthy subjects. In contrast, other studies showed that biomarker levels in CSF can be elevated in patients without SCI. ${ }^{22,27,31,32}$ For example, patients with a period of aortic clamping and patients with a whiplash trauma may have elevated biomarker levels in CSF without neurologic deficits. It is possible that these patients have a subclinical injury of the spinal cord with absent neurological deficits. For instance, in the aortic clamping group, there may have been ischemic spinal cord damage to some extent with concomitant elevation of biomarkers, but without neurological deficits. $^{22,31,32}$ This means that there is a 'false positive' range of biomarker elevations. Considering the absence of neurologic deficits as the 'gold standard' for the absence of SCI, a certain elevation of biomarker concentration should be regarded as normal. Furthermore, the NSE and S-100 $\beta$ serum levels can become artificially elevated after polytrauma, hemolysis and poor resuscitation. ${ }^{13,37,50,51}$ The role of NSE and S-100 $\beta$ in polytraumatized patients as markers of nervous tissue damage is therefore questionable as increased serum levels of NSE and S-100 $\beta$ are also identified in critically ill patients without brain injury. Traumatized fat, muscle, bone marrow and several abdominal organs have been identified as the source for these increased serum levels of NSE and S-100 $\beta$ in trauma patients without CNS injury. ${ }^{50,51}$ 
Increased concentrations of biomarkers S-100 $\beta$, NSE, NFL and GFAP have been identified in serum and CSF after SCI, but how these concentrations relate to neurological outcome remains unclear. Only two studies have identified patients as having an unfavorable motor function in cases of persistently increased serum levels of S-100 $\beta .^{29,30}$ The studies of Marquardt et al. ${ }^{29,30}$ identified that a longer period of persistently elevated $S-100 \beta$ concentrations in serum was significantly related to lower extremity muscle power outcome.

To our knowledge, only one study has investigated biomarkers in traumatic SCI. ${ }^{27}$ This study, however, has several limitations. For example, this study included only six SCI patients, the lumbar puncture was performed with a range of 1-21 days after the initial trauma, no statistical analysis was performed, and concentrations were not correlated to neurologic deficit or functional outcome. Although this study is the first to suggest the possibility of quantifying the degree of nerve cell damage after traumatic SCI, no definitive conclusions can be drawn about the diagnostic role of biomarkers in traumatic SCI patients.

\section{Conclusion}

Although several studies have identified increased concentrations of neurochemical biomarkers, most studies identified these biomarkers in patients at risk for ischemic SCI during and after TAAA surgery. To date, only one study investigating biomarkers in traumatic SCI has been performed. Moreover, none of the available human studies correlated the concentrations of biomarkers with adequate measures of neurological outcome. Therefore, care must be taken to control for several clinical variables to ensure accurate results and to prevent invalid conclusions.

Considering the limited availability of sensitive prognostic modalities for the evaluation of traumatic SCI, it is our opinion that further clinical trials in SCI are necessary to evaluate the applicability of biomarkers as a diagnostic tool in patients with traumatic SCI. We are currently performing a multicenter study to investigate the diagnostic role of neurochemical biomarkers in traumatic SCI within the consortium of the European Multicentre Study on Human Spinal Cord Injury (EM-SCI; www.emsci.org).

\section{References}

1 Bracken MB, Shepard MJ, Holford TR, Leo-Summers L, Aldrich EF, Fazl M et al. Administration of methylprednisolone for 24 or $48 \mathrm{~h}$ or tirilazad mesylate for $48 \mathrm{~h}$ in the treatment of acute spinal cord injury. Results of the Third National Acute Spinal Cord Injury Randomized Controlled Trial. National Acute Spinal Cord Injury Study. JAMA 1997; 277: 1597-1604.

2 Papadopoulos SM, Selden NR, Quint DJ, Patel N, Gillespie B, Grube S. Immediate spinal cord decompression for cervical spinal cord injury: feasibility and outcome. J Trauma 2002; 52: 323-332.

3 Steeves JD, Lammertse D, Curt A, Fawcett JW, Tuszynski MH, Ditunno JF et al. Guidelines for the conduct of clinical trials for spinal cord injury (SCI) as developed by the ICCP panel: clinical trial outcome measures. Spinal Cord 2007; 45: 206-221.
4 Schaefer DM, Flanders AE, Osterholm JL, Northrup BE. Prognostic significance of magnetic resonance imaging in the acute phase of cervical spine injury. J Neurosurg 1992; 76: 218-223.

5 Lammertse D, Dungan D, Dreisbach J, Falci S, Flanders A, Marino $\mathrm{R}$ et al. Neuroimaging in traumatic spinal cord injury: an evidence-based review for clinical practice and research. $J$ Spinal Cord Med 2007; 30: 205-214.

6 Brown PJ, Marino RJ, Herbison GJ, Ditunno Jr JF. The 72-h examination as a predictor of recovery in motor complete quadriplegia. Arch Phys Med Rehabil 1991; 72: 546-548.

7 Marino RJ, Graves DE. Metric properties of the ASIA motor score: subscales improve correlation with functional activities. Arch Phys Med Rehabil 2004; 85: 1804-1810.

8 Flanders AE, Spettell CM, Tartaglino LM, Friedman DP, Herbison GJ. Forecasting motor recovery after cervical spinal cord injury: value of MR imaging. Radiology 1996; 201: 649-655.

9 Miyanji F, Furlan JC, Aarabi B, Arnold PM, Fehlings MG. Acute cervical traumatic spinal cord injury: MR imaging findings correlated with neurologic outcome - prospective study with 100 consecutive patients. Radiology 2007; 243: 820-827.

10 Noppe M, Crols R, Andries D, Lowenthal A. Determination in human cerebrospinal fluid of glial fibrillary acidic protein, S-100 and myelin basic protein as indices of non-specific or specific central nervous tissue pathology. Clin Chim Acta 1986; 155: 143-150.

11 Lamers KJ, van Engelen BG, Gabreels FJ, Hommes OR, Borm GF, Wevers RA. Cerebrospinal neuron-specific enolase, S-100 and myelin basic protein in neurological disorders. Acta Neurol Scand 1995; 92: 247-251.

12 Mokuno K, Kiyosawa K, Sugimura K, Yasuda T, Riku S, Murayama $\mathrm{T}$ et al. Prognostic value of cerebrospinal fluid neuron-specific enolase and S-100b protein in Guillain-Barre syndrome. Acta Neurol Scand 1994; 89: 27-30.

13 Floyd E, McShane TM. Development and use of biomarkers in oncology drug development. Toxicol Pathol 2004; 32(Suppl 1): 106-115.

14 Kochanek PM, Berger RP, Bayir H, Wagner AK, Jenkins LW, Clark RS. Biomarkers of primary and evolving damage in traumatic and ischemic brain injury: diagnosis, prognosis, probing mechanisms, and therapeutic decision making. Curr Opin Crit Care 2008; 14: 135-141.

15 Vaage J, Anderson R. Biochemical markers of neurologic injury in cardiac surgery: the rise and fall of S100beta. J Thorac Cardiovasc Surg 2001; 122: 853-855.

16 Rosengren LE, Karlsson JE, Karlsson JO, Persson LI, Wikkelso C. Patients with amyotrophic lateral sclerosis and other neurodegenerative diseases have increased levels of neurofilament protein in CSF. J Neurochem 1996; 67: 2013-2018.

17 Miller DH. Biomarkers and surrogate outcomes in neurodegenerative disease: lessons from multiple sclerosis. NeuroRx 2004; 1: 284-294.

18 Pleines UE, Morganti-Kossmann MC, Rancan M, Joller H, Trentz O, Kossmann T. S-100 beta reflects the extent of injury and outcome, whereas neuronal specific enolase is a better indicator of neuroinflammation in patients with severe traumatic brain injury. J Neurotrauma 2001; 18: 491-498.

19 Hardemark HG, Ericsson N, Kotwica Z, Rundstrom G, MendelHartvig I, Olsson Y et al. S-100 protein and neuron-specific enolase in CSF after experimental traumatic or focal ischemic brain damage. J Neurosurg 1989; 71: 727-731.

20 Jauch EC, Lindsell C, Broderick J, Fagan SC, Tilley BC, Levine SR. Association of serial biochemical markers with acute ischemic stroke: the National Institute of Neurological Disorders and Stroke recombinant tissue plasminogen activator Stroke Study. Stroke 2006; 37: 2508-2513.

21 Berger RP, Adelson PD, Richichi R, Kochanek PM. Serum biomarkers after traumatic and hypoxemic brain injuries: insight into the biochemical response of the pediatric brain to inflicted brain injury. Dev Neurosci 2006; 28: 327-335.

22 van Dongen EP, ter Beek HT, Schepens MA, Morshuis WJ, Haas FJ, de Boer A et al. The relationship between evoked potentials and measurements of S-100 protein in cerebrospinal fluid during and 
after thoracoabdominal aortic aneurysm surgery. I Vasc Surg 1999; 30: 293-300.

23 van Dongen EP, ter Beek HT, Boezeman EH, Schepens MA, Langemeijer HJ, Aarts LP. Normal serum concentrations of S-100 protein and changes in cerebrospinal fluid concentrations of S-100 protein during and after thoracoabdominal aortic aneurysm surgery: is S-100 protein a biochemical marker of clinical value in detecting spinal cord ischemia? J Vasc Surg 1998; 27: 344-346.

24 Brunnekreef GB, Heijmen RH, Gerritsen WB, Schepens MA, ter Beek HT, van Dongen EP. Measurements of cerebrospinal fluid concentrations of S100beta protein during and after thoracic endovascular stent grafting. Eur J Vasc Endovasc Surg 2007; 34: 169-172.

25 Brisby H, Olmarker K, Rosengren L, Cederlund CG, Rydevik B. Markers of nerve tissue injury in the cerebrospinal fluid in patients with lumbar disc herniation and sciatica. Spine 1999; 24: 742-746.

26 Ohta M, Ohta K, Nishimura M, Saida T. Detection of myelin basic protein in cerebrospinal fluid and serum from patients with HTLV-1-associated myelopathy/tropical spastic paraparesis. Ann Clin Biochem 2002; 39: 603-605.

27 Guez M, Hildingsson C, Rosengren L, Karlsson K, Toolanen G. Nervous tissue damage markers in cerebrospinal fluid after cervical spine injuries and whiplash trauma. I Neurotrauma 2003; 20: 853-858.

28 Shiiya N, Kunihara T, Miyatake T, Matsuzaki K, Yasuda K. Tau protein in the cerebrospinal fluid is a marker of brain injury after aortic surgery. Ann Thorac Surg 2004; 77: 2034-2038.

29 Marquardt G, Setzer M, Seifert V. Protein S-100b as serum marker for prediction of functional outcome in metastatic spinal cord compression. Acta Neurochir (Wien) 2004; 146: 449-452.

30 Marquardt G, Setzer M, Seifert V. Protein S-100b for individual prediction of functional outcome in spinal epidural empyema. Spine 2004; 29: 59-62.

31 Winnerkvist A, Anderson RE, Hansson LO, Rosengren L, Estrera AE, Huynh TT et al. Multilevel somatosensory evoked potentials and cerebrospinal proteins: indicators of spinal cord injury in thoracoabdominal aortic aneurysm surgery. Eur J Cardiothorac Surg 2007; 31: 637-642.

32 Khaladj N, Teebken OE, Hagl C, Wilhelmi MH, Tschan C, Weissenborn $\mathrm{K}$ et al. The role of cerebrospinal fluid S100 and lactate to predict clinically evident spinal cord ischaemia in thoraco-abdominal aortic surgery. Eur J Vasc Endovasc Surg 2008; 36: 11-19.

33 Skouen JS, Brisby H, Otani K, Olmarker K, Rosengren L, Rydevik B. Protein markers in cerebrospinal fluid in experimental nerve root injury. A study of slow-onset chronic compression effects or the biochemical effects of nucleus pulposus on sacral nerve roots. Spine 1999; 24: 2195-2200.

34 Ma J, Novikov LN, Karlsson K, Kellerth JO, Wiberg M. Plexus avulsion and spinal cord injury increase the serum concentration of S-100 protein: an experimental study in rats. Scand J Plast Reconstr Surg Hand Surg 2001; 35: 355-359.

35 Nagy G, Dzsinich C, Selmeci L, Sepa G, Dzsinich M, Kekesi V et al. Biochemical alterations in cerebrospinal fluid during thoracoab- dominal aortic cross-clamping in dogs. Ann Vasc Surg 2002; 16: 436-441.

36 Cornefjord M, Nyberg F, Rosengren L, Brisby H. Cerebrospinal fluid biomarkers in experimental spinal nerve root injury. Spine 2004; 29: 1862-1868.

37 Loy DN, Sroufe AE, Pelt JL, Burke DA, Cao Q, Talbott JF et al. Serum biomarkers for experimental acute spinal cord injury: rapid elevation of neuron-specific enolase and S-100beta. Neurosurgery 2005; 56: 391-397.

38 Cao F, Yang XF, Liu WG, Hu WW, Li G, Zheng XJ et al. Elevation of neuron-specific enolase and S-100beta protein level in experimental acute spinal cord injury. J Clin Neurosci 2008; 15: 541-544.

39 Donato R. S-100 proteins. Cell Calcium 1986; 7: 123-145.

40 Marangos PJ, Schmechel D. The neurobiology of the brain enolases. Essays Neurochem Neuropharmacol 1980; 4: 211-247.

41 Olmarker K, Rydevik B, Holm S. Edema formation in spinal nerve roots induced by experimental, graded compression. An experimental study on the pig cauda equina with special reference to differences in effects between rapid and slow onset of compression. Spine 1989; 14: 569-573.

42 Kunihara T, Shiiya N, Yasuda K. Changes in S100beta protein levels in cerebrospinal fluid after thoracoabdominal aortic operations. I Thorac Cardiovasc Surg 2001; 122: 1019-1020.

43 Schachner M, Hedley-Whyte ET, Hsu DW, SchoonMaker G, Bignami A. Ultrastructural localization of glial fibrillary acidic protein in mouse cerebellum by immunoperoxidase labeling. J Cell Biol 1977; 75: 67-73.

44 Lasek RJ, Phillips L, Katz MJ, utilio-Gambetti L. Function and evolution of neurofilament proteins. Ann NY Acad Sci 1985; 455: 462-478.

45 Lam T, Noonan VK, Eng JJ. A systematic review of functional ambulation outcome measures in spinal cord injury. Spinal Cord 2008; 46: 246-254.

46 Cohen SR, Brooks BR, Herndon RM, McKhann GM. A diagnostic index of active demyelination: myelin basic protein in cerebrospinal fluid. Ann Neurol 1980; 8: 25-31.

47 Campagnoni AT. Molecular biology of myelin proteins from the central nervous system. J Neurochem 1988; 51: 1-14.

48 Binder LI, Frankfurter A, Rebhun LI. The distribution of tau in the mammalian central nervous system. J Cell Biol 1985; 101: 1371-1378.

49 Ost M, Nylen K, Csajbok L, Ohrfelt AO, Tullberg M, Wikkelso C et al. Initial CSF total tau correlates with 1-year outcome in patients with traumatic brain injury. Neurology 2006; 67: 1600-1604.

50 Pelinka LE, Hertz H, Mauritz W, Harada N, Jafarmadar M, Albrecht $\mathrm{M}$ et al. Nonspecific increase of systemic neuron-specific enolase after trauma: clinical and experimental findings. Shock 2005; 24: 119-123.

51 Routsi C, Stamataki E, Nanas S, Psachoulia C, Stathopoulus A, Koroneos A et al. Increased levels of serum S100B protein in critically ill patients without brain injury. Shock 2006; 26: 20-24. 